\title{
THE EFFECT OF ACADEMIC PROCRASTINATION ON THE ACCOUNTING LEARNING ACHIEVEMENT USING SELF-EFFICACY AS MODERATING VARIABLE AT SMK YPKK 1 SLEMAN
}

\author{
PENGARUH PROKRASTINASI AKADEMIK TERHADAP PRESTASI BELAJAR \\ AKUNTANSI DENGAN SELF-EFFICACY SEBAGAI VARIABEL MODERASI DI SMK \\ YPKK 1 SLEMAN
}

Oleh:

Ismi Nur Rahmah

Accounting Education Department

isminurrahmah@gmail.com

\begin{abstract}
This research has two objectives. First, it is aimed to determine the effect of Academic Procrastination on the Accounting Learning Achievement in Accounting Study Program at grade X of SMK YPKK 1 Sleman academic year of 2014/2015. Second, it is amied to determine the effect of Academic Procrastination on the Accounting Learning Achievement through Self-efficacy as moderating variable in Accounting Study Program at grade $X$ of SMK YPKK 1 Sleman academic year of 2014/2015

The population in this study was the students in Study Program at grade X of SMK YPKK 1 Sleman consists of 54 students. Data collection in this research were Questionnaire and Documentation. The questionnaires consisted of academic procrastination and selfefficacy instruments while the documentation was used to obtain Accounting Learning Achievement data.

Research results showed that: (1) There is a significant negative effect of Academic Procrastination on the Accounting Learning Achievement in Accounting Study Program at grade X of SMK YPKK 1 academic year of 2014/2015, with rxly $=0.575 ; r 2 x 1 y=0.331$; $t$ count $-5.068>$ t-table and sig $0.000<0.05$; (2) There is significant negative effect of Academic Procrastination on the Accounting Learning Achievement through Self-efficacy as moderating variable in Accounting Study Program at grade X of SMK YPKK 1 academic year of 2014/2015, with rxly $=0.699 ; r 2 x l y=0.489 ;$ t-count $-2.030>t$-table and sig $0.048<$ 0.050 .
\end{abstract}

Keywords: Accounting Learning Achievement, Academic Procrastination, Self-efficacy

\begin{abstract}
Abstrak
Penelitian ini mempunyai dua tujuan. Pertama, bertujuan untuk menentukan pengaruh Prokrastinasi Akademik terhadap Prestasi Belajar Siswa jurusan Akuntansi kelas X di SMK YPKK 1 Sleman tahun ajaran 2014/2015. Kedua, bertujuan untuk menentukan pengaruh Prokrastinasi Akademik terhadap Prestasi Belajar Akuntansi melalui Self-efficacy sebagai variabel moderasi pada siswa jurusan Akuntansi kelas X di SMK YPKK 1 Sleman tahun ajaran 2014/2015.

Populasi pada penelitian ini adalah siswa di jurusan Akuntansi kelas X di SMK YPKK 1 Sleman yang berjumlah 54 siswa. Pengumpulan data dalam penelitian ini adalah kuesioner dan dokumentasi. Kuesioner terdiri dari angket Prokrastinasi Akademik dan Angket Selfefficacy sedangkan dokumentasi digunakan untuk mendapatkan data Prestasi Belajar Akuntansi.
\end{abstract}


Hasil penelitian ini menunjukkan bahwa: (1) terdapat pengaruh negatif dan signifikan pada Prokrastinasi Akademik terhadap Prestasi Belajar Akuntansi siswa jurusan Akuntansi kelas X SMK YPKK 1 Sleman tahun ajaran 2014/2015, dengan $\mathrm{rx} 1 \mathrm{y}=0.575 ; \mathrm{r} 2 \mathrm{x} 1 \mathrm{y}=0.331$; t-hitung $-5.068>$ t-tabel dan signifikansi $0.000<0.05$; (2) terdapat pengaruh negatif dan signifikan pada Prokrastinasi Akademik terhadap Prestasi Belajar Akuntansi melalui Selfefficacy sebagai variabel moderasi siswa jurusan akuntansi kelas X di SMK YPKK 1 tahun ajaran 2014/2015, dengan $\mathrm{rx} 1 \mathrm{y}=0.699 ; \mathrm{r} 2 \mathrm{x} 1 \mathrm{y}=0.489 ; \mathrm{t}$-hitung $-2.030>\mathrm{t}$-tabel dan signifikansi $0.048<0.05$.

Kata kunci: Prestasi Belajar Akuntansi, Prokrastinasi Akademik, Self-efficacy

\section{INTRODUCTION}

Education has an important role in the national development in indicating the quality, identity and national progress. Through education, people can develop their potential to become qualified individuals, as it is written in the Law No. 2/2003 Article 1, paragraph (1) of the National Education System, "Education is a conscious and deliberate effort to create an atmosphere of learning and the learning process so learners are actively developing his/her potential to have the spiritual strength of religious, self-control, personality, intelligence, noble character and skills that is by herself/himself, society, nation, and state". From the definition it can be concluded that education is directed to make people have good morals, personality, knowledge, and skill, in efforts to the national education.

Discipline, creative, and high work ethos are the indicators of qualified human resources (Ghufron, 2004). In the academic, the student can be considered as qualified human resources if they can show behavior that reflects the attitude of discipline, creative and high work ethos in school tasks. However, a phenomenon happens in the academic is that the students' behavior does not reflect discipline of which causes decrease students' quality. The student quality will be reflected in students' achievement. The indisciplinary of students in their schoolwork will ultimately affect student learning achievement.
Sumadi Suryabrata (2002: 297) defines that learning achievement is as a value of final formulation which can be given by teachers on student achievement progress during a specific period. Student learning achievement can be known by using a standard to determine the success of students in the participating in learning activities. The standards outlined in the criteria is called Minimal Completeness Criteria (MCC) or known as Kriteria Ketuntasan Minimal (KKM). MCC will determine the level of students' achievement. Higher scores lead to higher learning achievement.

In the learning process, the students meet various academic problems which can inhibit them in achieving minimum completeness criteria values, for examples are the timing of learning, choosing the method of learning to prepare for the exam, completing school tasks and etc. If a person, in this case is the vocational school's student, has difficulty to do something according to the deadline, often delay, prepare everything to much and fail to complete the task within its time limit, it can be said as procrastination (Ghufron, 2010). Procrastination or delay according to some results, is one of the issues in the society and the students in particular. About $25 \%$ to $75 \%$ of students reported that procrastination is one of the issues in the academic environment (Ferrari in Ghufron, 2003).

Based on the pre-survey conducted by researcher through interviews to financial 
accounting teachers in Accounting program grade $\mathrm{X}$ at YPKK 1 Sleman, it is known that students often ignore their homework and also unable to collect the task timely. The observations conducted by the researcher to the students at Accounting study program Grade $\mathrm{X}$ of YPKK 1 Sleman showed there were $20 \%$ of students whose academic achievement were still low because they had MCC below 77 .

Academic procrastination is a behavior of delaying work and completing academic assignments (Ghufron, 2010).

The influence of self-efficacy in a way of thinking would be able to direct motivation and actions to achieve a positive outcome. Beliefs of students to be able to do the task often affect the efforts to complete the task. Different effort will reflect on different learning achievement. Basically all of the efforts to achieve depend on ourselves. Therefore, improving self-efficacy is very important because it will help students choose activities that can motivate themselves to use their capabilities.

In this study, researcher is trying to use a variable that is suspected of having relevance and including into one of a person's mental condition, these variables are self-efficacy. Self-efficacy been selected as moderating variable that refers to one aspect of academic procrastination, namely perceived ability, which can be strengthen or weaken the influence of academic procrastination on learning achievement. Thus researcher conducted a research about procrastination entitles "The Effect of Academic Procrastination on The Accounting Learning Achievement using Self-Efficacy as Moderating Variable at SMK YPKK 1 Sleman.”

\section{A. Research Method \\ 1. Research Type}

This study is a causal comparative research. This study used quantitative research methods. The results of this research were quantitative data.

\section{Research Location and Time}

This research was conducted in class $X$ SMK YPKK 1 Sleman located at Jalan Sayangan No. 5, Mejing, Ambarketawang, Gamping. It was conducted in March June 2015.

\section{Research Population}

The subject of this research was 54 students of Class X AK at SMK YPKK 1 Sleman academic year of 2014/2015. Thus, this study was a populative research, which use the whole population as a respondent; in other words it was called census research..

\section{Data, Instrument and technique analysis data}

a) Data

This research used a closed questionnaire. This questionnaire consists of statements that provide information for researchers on the Academic Procrastination and Self-efficacy of the students grade $\mathrm{X}$ Accounting Study Program at SMK YPKK 1 Sleman academic year of 2014/2015. Academic Procrastination Lattice and Self-efficacy of each variable can be shown in table as below:

Table 1. The Instruments of Academic Procrastination and Selfefficacy

\begin{tabular}{|l|l|c|}
\hline No & \multicolumn{1}{|c|}{ Variable } & $\begin{array}{c}\text { Number of } \\
\text { Statement: }\end{array}$ \\
\hline \multirow{4}{*}{1} & & $1^{*}, 2,3,4,5,6$, \\
& & $7,8,9,10,11$, \\
& Academic & $12,13^{*}, 14^{*}, 15$, \\
& Procrastination & $16^{*}, 17^{*}, 18,19$, \\
& & $20^{*}, 21,22^{*}$, \\
& & $23,24,25$ \\
\hline \multirow{3}{*}{2.} & \multirow{2}{*}{ Self-Efficacy } & $1 *, 2,3^{*}, 4,5$, \\
& & $11,12,13,14,14$, \\
& & $15,16,17^{*}, 18$, \\
\hline
\end{tabular}




\begin{tabular}{|l|c|}
\hline & $19,20,21,22$, \\
& $23^{*}, 24,25^{*}$, \\
& $26,27,28^{*}, 29$ \\
\hline
\end{tabular}

*) Negative statement

Measurements used Likert scale questionnaire which has score from very positive to very negative. For analysis quantitative and avoid hesistant answers from respondents then it were modified by Likert scale.

Table 2. The Alternative Score of the Academic Procrastination and Self-Efficacy Instrument.

\begin{tabular}{|c|c|c|c|}
\hline $\begin{array}{c}\text { Positive } \\
\text { statement }\end{array}$ & Score & $\begin{array}{c}\text { Negative } \\
\text { statement }\end{array}$ & Score \\
\hline $\begin{array}{c}\text { Strongly } \\
\text { Agree }\end{array}$ & 4 & $\begin{array}{c}\text { Strongly } \\
\text { Agree }\end{array}$ & 1 \\
\hline Agree & 3 & Agree & 2 \\
\hline Disagree & 2 & Disagree & 3 \\
\hline $\begin{array}{c}\text { Strongly } \\
\text { Disagree }\end{array}$ & 1 & $\begin{array}{c}\text { Strongly } \\
\text { Disagree }\end{array}$ & 4 \\
\hline
\end{tabular}

In this study, the documentation was used to gain the data about the number of students and the Accounting Learning Achievement of grade X Accounting Study Program SMK YPKK 1 students through daily tests and Midterm test results in the academic year of 2014/2015.

\section{b) Data Analysis Technique}

\section{1) Instrument Testing}

Instrument testing, valid and reliable instrument is a necessary condition to obtain valid and reliable result of research. Therefore, trial of the instrument is needed to obatain a good instrument. The instrument testing was conducted in Accounting Study Program at Grade $X$ of SMK YPKK 1 Sleman.

\section{(a) Validity Test}

The formula validity test is using Product Moment from Karl Pearson

$$
\mathrm{r}_{\mathrm{xy}}=\frac{N \sum X Y-\left(\sum X\right)\left(\sum Y\right)}{\sqrt{\left(N \sum X^{2}-\left(\sum X\right)^{2}\right)\left\{N \sum Y^{2}-\left(\sum Y\right)^{2}\right\}}}
$$

Note:

rxy $=$ coefficient product moment correlation

$\mathrm{N} \quad=$ number of samples

$\sum X=$ total score of variable item

$\sum X^{2}=$ total score squared of variable $X$

$\sum Y \quad=$ total score of variables

$\sum Y^{2}=$ total score squared of variable $\mathrm{Y}$

$\sum X Y \quad=$ multiple of the $\mathrm{X}$ and $\mathrm{Y}$

Table 3. The Summary of Validity Test

\begin{tabular}{|c|c|c|c|c|}
\hline Variable & $\begin{array}{l}\text { The } \\
\text { numb } \\
\text { er of } \\
\text { item }\end{array}$ & $\begin{array}{l}\text { The } \\
\text { numb } \\
\text { er of } \\
\text { invali } \\
\text { d }\end{array}$ & $\begin{array}{l}\text { Invali } \\
\text { d item }\end{array}$ & $\begin{array}{l}\text { The } \\
\text { numb } \\
\text { er of } \\
\text { valid }\end{array}$ \\
\hline $\mathrm{X} 1$ & 25 & 1 & 15 & 24 \\
\hline $\mathrm{X} 2$ & 30 & 3 & 7,8, & 27 \\
\hline Total & 55 & 4 & & 51 \\
\hline
\end{tabular}

The result of validity test showed that there were 24 valid items for Academic Procrastination instrument and 27 valid items for Self-efficacy instrument. The valid items was used to collect data.

\section{(b) Reliability Test}

The technique is formulated as follows:

$$
\mathrm{r}^{11}=\left[\frac{k}{(k-1)}\right]\left[1-\frac{\sum \sigma b^{2}}{\sigma t^{2}}\right]
$$

Note:

$\mathrm{r}_{11}=$ Reliability Instrument

$\mathrm{K}=$ The questions number

$\sum \sigma b^{2}=$ Total Variance item

$\sigma t^{2}=$ Total Variance

Below is the score categories of correlation coefficient table. 
Table 4. Correlation Coefficient of Reliability level

\begin{tabular}{|c|c|}
\hline Rated r & Interpretation \\
\hline $0,800-1,000$ & Very High \\
\hline $0,600-0,799$ & High \\
\hline $0,400-0,599$ & Enough \\
\hline $0,200-0,399$ & Low \\
\hline $0,000-0,199$ & Very Low \\
\hline
\end{tabular}

The conclusions of Academic Procrastination and Self-efficacy instrument are reliable. The results are included the following table:

Table 5. The Summary of Reliability Test

\begin{tabular}{|c|l|c|c|}
\hline No & Variable & $\begin{array}{c}\text { Coeff } \\
\text { alfa } \\
\text { chronbach }\end{array}$ & Category \\
\hline 1 & $\begin{array}{l}\text { Academic } \\
\text { Procrasti } \\
\text { Nation } \\
\text { (X1) }\end{array}$ & 0,927 & Very High \\
\hline 2 & $\begin{array}{l}\text { Self- } \\
\text { efficacy } \\
(\mathrm{X} 2)\end{array}$ & 0,749 & High \\
\hline
\end{tabular}

\section{2) Classical Assumption Test}

\section{(a) Linearity Test}

Linearity test is used to know between independent variable and dependent variable whether it is linear or not.

Table 6. The summary of linearity test result

\begin{tabular}{|c|l|c|c|c|}
\hline No & $\begin{array}{l}\text { Variab } \\
\text { le }\end{array}$ & $\begin{array}{c}\mathbf{F} \\
\text { coun } \\
\mathbf{t}\end{array}$ & $\begin{array}{c}\mathbf{F} \\
\text { tabl } \\
\mathbf{e}\end{array}$ & $\begin{array}{c}\text { Descrip } \\
\text { tion }\end{array}$ \\
\hline 1 & $\mathrm{X} 1-\mathrm{Y}$ & $\begin{array}{c}1,34 \\
4\end{array}$ & 3.18 & Linier \\
\hline 2 & $\mathrm{X} 2-\mathrm{Y}$ & $\begin{array}{c}3,00 \\
8\end{array}$ & 3.18 & Linier \\
\hline
\end{tabular}

This is applies for all the independent variables on the dependent variable. It can be concluded that they have linear relationship and thus the regresion analysis can be continued. (b) Multicollinearity Test

Table 7. Summary of Multicollinierity Test Result

\begin{tabular}{|c|c|c|c|}
\hline Variabel & $\mathbf{X}_{\mathbf{1}}$ & $\mathbf{X}_{\mathbf{2}}$ & Description \\
\hline $\mathrm{X}_{1}$ & 1 & 0,769 & No \\
$\mathrm{X}_{2}$ & 0,769 & 1 & Multicollinierity \\
\hline
\end{tabular}

correlation between all independent variables is quite high at 0.769 or $76.9 \%$. This value is smaller than 0,900 . It can be concluded that there is no multicollinearity.

\section{(c) Heteroscedasticity Test}

Figure 1. Heteroscedasticity Test Result

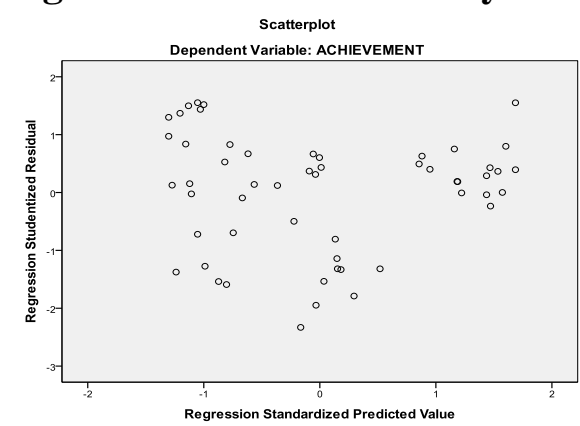

Based on pie chart above it can be seen that the distribution data is irregular and not form a specific pattern, as well as spread on top and under the number 0 on the $\mathrm{Y}$ axis. So it can be concluded that heteroscedasticity not occured.

Table 8. Glejser Test Result

\begin{tabular}{|c|c|}
\hline Model & Sig \\
\hline $\begin{array}{c}\text { Academic } \\
\text { Procrastination }\end{array}$ & 0,764 \\
\hline Self-efficacy & 0,069 \\
\hline
\end{tabular}

From the output above it can be seen the value of the significance from two independent variables more than 0.05. It can be concluded that there was no heteroskedastisity on the regression model. 


\section{RESEARCH \\ RESULT \\ AND DISCUSSION}

\section{Accounting Learning Achievement}

Based on the data collected it is known that the highest score obtained by the students was 89 and the lowest score was 55 . Based on the data analyzed the mean value was 70.31 ; the median was 71 ; the mode was 78; and a deviation standard was 8.303 .

Based on the tendency categories, can be concluded that Accounting Learning Achievement on competency standards of Accounting for Service Companies in Accounting Study Program at Grade $X$ of SMK YPKK 1 Sleman Academic Year of 2014/2015 was mostly in the incomplete category having a number of 38 students $(70.37 \%)$.

\section{Academic Procrastination}

Academic Procrastination variable is measured by questionnaire which is distributed to 54respondents. The questionnaire consists of 24 items. There are four alternative answers with the highest scores 4 and the lowest scores 1 . Based on analysis, Academic Procrastination vshowed highest score is 71 and the lowest score is 46 , while the mean value is 60.65; Median 61.50; the Mode 50 and deviation standard is 7.222.

According to the tendency categories, it shows that the $96.30 \%$ of 54 respondents is achieving Academic Procrastination categorized as High.

\section{Self-efficacy}

The questionnaire consisted of 27 items involved four alternative answers with the highest score 4 and the lowest score 1 . Based on statistics testing, it was showed that the highest score was 81 and the lowest score was 52 , while the mean value was 65.07 ; the median was 65 ; the mode was 55 and standard deviation is 9.609 .

According to the tendency categories, it shows that the most of respondents $(92,59$
$\%$ ) are achieving Self-efficacy categorized as Middle.

4. Hypothesis Testing

a) The effect Academic Procrastination on the Accounting Learning Achievement.

Table 9. The summary of Academic Procrastination t Test on Learning Achievement

\begin{tabular}{|c|c|c|c|c|c|c|c|c|c|}
\hline \multirow{2}{*}{ Var } & \multicolumn{2}{|c|}{$\begin{array}{c}\text { Count of } \mathrm{r} \\
\text { dan } \mathrm{r}^{2}\end{array}$} & \multicolumn{3}{|c|}{$\mathrm{T}$ count } & \multirow{2}{*}{ Coef } & Const & \multirow{2}{*}{ Desc } \\
\cline { 2 - 6 } & $\mathrm{r}_{\mathrm{xll}}$ & $r_{x I y}{ }^{2}$ & $\mathrm{~T}_{\text {count }}$ & $\mathrm{t}_{\text {tabel }}$ & Sig. & & & \\
\hline $\mathrm{Xl}$ & $\mathrm{Y}$ & 0.575 & 0.331 & - & 1.675 & 0.00 & -0.66 & 110.29 & $\begin{array}{c}\text { Negative- } \\
\text { Significant }\end{array}$ \\
\hline
\end{tabular}

Source: Processed Primary Data, 2015

1) Regression Line Equations

From -0.660 as the coefficient predictor and 110.290 as the constant number above, it can be arranged that the regression line of one predictor equation is $\mathrm{Y}=110,290$ $0,660 \mathrm{X} 1$. It means the regression coefficient is negative for -0.660 which also implies that the Accounting Learning Achievement (Y) decrease to 0,660 when the Academic Procrastination (X1) increased to 1 .

2) The Correlation Coefficient $\left(\mathrm{r}_{\mathrm{x} 1 \mathrm{y}}\right)$ dan Coefficient of Determination $\left(r_{x 1 y}^{2}\right)$

Simple regression analysis with one predictor show that the correlation coefficient ( $\left.\mathrm{r} \_\mathrm{x} 1 \mathrm{y}\right)$ is 0.575 and the coefficient of determination $\left(r_{-} \times 1 y^{\wedge} 2\right)$ is 0.331. This means that the Academic Procrastination affecting $33.1 \%$ of Accounting Learning Achievement. This shows there are still $66.9 \%$ of other variables affecting the Accounting Learning Ahievement.

3) Test the significance of the t-test According to the analysis of data findings, it is gained that the t-count value is -5.068 , while the significant value is $0.000<$ level of significant 0.05 or t-count $-5.068>\mathrm{t}$ table 1.675. It means that there is significant negative influence from the Academic Procrastination on the 
Acounting Learning Achievement in grade X Accounting Study Program SMK YPKK 1 Sleman Academic Year 2014/2015.

Based to the result above, the first hypothesis which states that "The Academic Procrastination is negatively influential to the Accounting Learning Achievement at Grade $\mathrm{X}$ Accounting Study Program SMK YPKK 1 Sleman Academic Year of 2014/2015" is supported.

5. The effect of Academic Procratination on the Accounting Learning Achievement using Selfefficacy as moderating variable.

Table 10. The Summary of MRA

\begin{tabular}{|c|c|c|c|c|c|c|c|c|}
\hline \multirow{2}{*}{ Variable } & \multirow{2}{*}{$\mathrm{R}$} & \multirow{2}{*}{$\begin{array}{c}\mathrm{R} \\
\text { Square }\end{array}$} & \multicolumn{3}{|c|}{$t$} & \multirow{2}{*}{$\begin{array}{l}\text { Coef } \\
\text { (Beta) }\end{array}$} & \multirow{2}{*}{$\mathrm{F}$} & \multirow{2}{*}{ Sig } \\
\hline & & & tcount & t table & $\mathrm{Sig}$ & & & \\
\hline Constants & & & & & & $.73,792$ & & \\
\hline $\begin{array}{c}\text { Academic } \\
\text { Procrastination } \\
(\mathrm{Xl}) \\
\end{array}$ & & & 1,816 & & 0,075 & 1,888 & & \\
\hline $\begin{array}{l}\text { Self-efficacy } \\
\text { (X2) }\end{array}$ & & & 2,508 & & 0,015 & 2,306 & & \\
\hline $\begin{array}{l}\text { MODERATE } \\
\left(\mathrm{X} 1^{*} \mathrm{X} 2\right)\end{array}$ & 0,699 & 0,489 & $-2,030$ & 1.675 & 0,048 & $-0,031$ & 15.952 & 0,000 \\
\hline
\end{tabular}

Source: Processed Primary Data, 2015

Regression analysis showed that the value Adjust $\mathrm{R}$ Square is 0.489 . It means that Academic Procrastination through Self-efficacy is able to explain $48,9 \%$ of Accounting Learning Achievement in Accounting Study Program at Grade $X$ of SMK YPKK 1 Sleman Academic Year of $2014 / 2015$. There rest $51,1 \%$ is explained by other variables.

The regression findings show that the value of $F$ count is 15.952 and the significance level value $=0.000<$ Level of Significant $=0.05$. It is implied that The Academic Procrastination through Selfefficacy is significant effect on Accounting Learning Achievement. F count $=15.925>$ $\mathrm{F}$ table $=3.18$ and the significance level value $0.000 \quad(<0.05)$. It shows that hypothesis 2 is supported.

From the table above can be arranged the regression equation is $\mathrm{Y}=-73,792+$
1,888 X_1 + 2,306X_2 - 0,031X_1 X_2. The equation shows that the regression coefficient is negative for $-0,031$ and the significance value is $0.048(<0.05)$. It is implied that there is significant negative effect. It means that Self-efficacy is able to weaken the influence of the Academic Procrastination on the Accounting Learning Achievement.

According to the analysis of data findings, it is gained that the t-count value is $-2,030$, while the significant value is $0,048<$ level of significant $=0.05$ or $\mathrm{t}$ count $=-2,030>$ t-table $=1.675$. It is implied that there is a significant negative effect of Self-efficacy as moderating variable on the relationship of Academic Procrastination and Accounting Learning Achievement.

Based to the result above, The second hypothesis which states that "Self-efficacy is weaken the influence of the Academic Procrastination on the Accounting Learning Achievement in Accounting Study Program at Grade X of SMK YPKK 1 Sleman Academic Year of 2014/2015." is supported.

\section{CONCLUSION AND SUGGESTION}

\section{Conclusion}

Based on the discussion that has been described previously, it could be concluded as follows:

1. The analysis findings showed that coefficient correlation $\left(\mathrm{r} \_\mathrm{x} 1 \mathrm{y}\right)$ is 0,575 ; coefficient determination $\left(\mathrm{r} \_\mathrm{x} 1 \mathrm{y}^{\wedge} 2\right)$ is 0,331 ; regression coefficients is $-0,660$ and the significance value is 0.000 . While the value of $t$-count is -5.068 the significance value is $0.000<$ level of significant is 0.05 or $\mathrm{t}$-count is $-5.068>$ $\mathrm{t}$-table is 1.675 . It means that there is a negative and significant influence from the Academic Procrastination on the Accounting Learning Achievement in grade $\mathrm{X}$ Accounting study program SMK YPKK 1 Sleman academic year 2014/2015. 
2. Based on the Moderating Regression Analysis findings showed that the value of coefficient is $-0,031$ and the significance value is $0.048 \quad(<0.050)$. While the t-count value is $-2,030$, while the significant value is $0,048<$ level of significant is 0.05 or $\mathrm{t}$-count is $-2,030>$ $\mathrm{t}$-table is 1.675 . It means that there is a negative moderating effect of Selfefficacy on the relationship of Academic Procrastination and Accounting Learning Achievement in grade $\mathrm{X}$ Accounting study program SMK YPKK 1 Sleman academic year 2014/2015.

\section{Suggestion}

a) For Future Researcher

It is expected that the next research would conduct comprehensive researches since in this study it was only two factors delivered related to the effect of The Accounting Learning Achievement, while the other factors have not been further studied yet.

b) The School and Teachers

The school and the teacher should control the student's activities, enforce discipline and make conducive learning environment, such as teachers give rewards for students who submit assignment before the deadline and give punishment for students who submit assignment after the deadline.

c) Students' parents

Students' parents should give motivation to their children in many ways, such as controlling tasks by asking what should be done, accompany children in learning and asking what their have difficulties in completing assignment.

d) For The Students

Thus students are expected to be able to handle it by increasing the intensity of learning; fix mistakes; active asking to the teachers and friends when find the problems in learning; reducing the time to play and passion for achievement. In addition students should increase their confidence that in fact they were able to overcome the problem by continuing learn and diligently reading.

\section{REFERENCE}

A. King, Laura. (2014). Psikologi Umum. Terj Brian Marwensdy. Jakarta: McGraw-Hill Education (Asia) and Salemba Humanika.

Alwisol. (2004). Psikologi Kepribadian. Malang: Universitas Muhammadiyah Malang.

A.M, Sardiman (2001). Interaksi Dan Motivasi Belajar Mengajar. Jakarta: Raja Grafindo Persada.

Ariani, Monicha Desy. (2013). Hubungan Antara Locus of Control, Efikasi Diri dan Motivasi Berprestasi dengan Prestasi Belajar Akuntansi Keuangan Siswa Kelas XI Program Keahlian Akuntansi SMK Negeri 1 Tempel Tahun Ajaran 2012/201. Skripsi: Pendidikan Akuntansi FE UNY.

Arifin, Zainal. (1991). Evaluasi Instruksional, Prinsip, Teknik, Prosedur. Bandung: PT. Remaja Rosdakarya.

(2009). Evaluasi Pendidikan. Bandung: PT Remaja Rosdakarya.

Arikunto, Suharsimi. (2010). Prosedur Penelitian Suatu Pendekatan Praktik. Jakarta: Rineka Cipta.

. (2013). Dasar-dasar Evaluasi Pendidikan. Jakarta: Bumi Aksara.

Bandura, A. (1994). Efikasi Diri. (http://www.des.emory.edu/mfp/B anEncy.html, diakses pada 25 Juni 2014. 
(1997). Self-efficacy, The Exercise of Control. New York: W.H. Freeman Company.

Baron, Byrne (2003). Psikologi Sosial, bahasa Indonesia language edition. Jakarta: Erlangga.

Chu, A. H. C., \& Choi, J. N. (2005). Rethinking Procrastination: Positive effects of "Active" procrastination behavior on attitudes and performance. Journal of Social Psycology, 145 (3), 245264.

Danim, Sodarwan . (2007). Metode penelitian untuk ilmu-ilmu perilaku. Jakarta: bumiaksara.

Duru dan Balkis. (2014). The Roles of Academic Procrastination Tendency on the Relationships among Self Doubt, Self Esteem and Academic Achievement. Journal of Education and Science. Vol 39 (173), 274-286.

Edwin dan Sia. (2007). Mahasiswa Versus Tugas: Prokrastinasi Akademik dan Conscientiousness. Anima Indonesian Psychological Journal. Vol 22, No.4, 352-374. Surabaya: Universitas Negeri Surabaya.

Ferarri, J. R., Johnson, J. L., \&McCown, W. G. (1995). Procrastination and Task Avoidance.New York: Plenum Press.

Ghufron M, Nur dan Rini Risnawita. (2010). Teori-teori Psikologi. Yogyakarta: Ar-Ruzz Media

Ghufton M, Nur. (2003). Hubungan Kontrol Diri dan Persepsi Remaja Terhadap Penerapan Disiplin Orangtua dengan Prokrastinasi Akademik. Jurnal Psikologi. Vol 3. Yogyakarta: UGM.
Ghozali, Imam. (2011). Aplilasi Analisis Multivariate dengan program IBM SPSS 19. Semarang: Badan Penerbit Universitas Diponegoro.

Lefton , Lester A. (1991) . Psychology. USA: McGraw-Hill.

Lowinger, Robert; He, Zhaomin; Lin, Miranda; Chang, Mei. (2014). The Impact of Academic Self-Efficacy, Acculturation Difficulties, and Language Abilities on Procrastination Behavior in Chinese International Students. Journal of Psychology, 141-152.

Putri, et. all. (2012). Hubungan antara Self-efficacy dengan Prokrastinasi Akademik pada Mahasiswa Program Studi Psikologi Universitas Sebelas Maret Surakarta. Vol 1 (2).

Robbins, S. P. (2001). Organizational Behavior $9^{\text {th }}$ Edition. New Jersey: Prentice Hall Inc.

Ruhimat, Toto; dkk. (2011). Kurikulum dan Pembelajaran. Jakarta: Raja Grafindo Persada.

Sejati, Natalia Putri. (2012). Hubungan antara efikasi diri dengan perilaku prokrastinasi akademik pada mahasiswa bimbingan dan konseling angkatan 2010 Universitas Negeri Yogyakrta. Skripsi: Bimbingan dan Konseling FIP UNY.

Slameto. (2010). Belajar dan FaktorFaktor yang Mempengaruhinya. Jakarta: Rineka Cipta.

Somantri, Hendri. (2009). Akuntansi SMK Seri A. bandung: CV ARMICO. 
Sudjiono, Anas. (2014). Pengantar Statistik Pendidikan. Jakarta: Rajawali Pers.

Sugiarto. (2008). Pengaruh Konsep Diri dan Efikasi Diri terhadap Prokrastinasi Akademik pada Mahasiswa Bimbingan dan Konseling. Skripsi: Bimbingan dan konseling FIP UNY.

Sugiyono. (2009). Statistik untuk Penelitian. Bandung: CV Alfabeta. (2013). Metode Penelitian Kombinasi. Bandung: CV Alfabeta.

Suharjo, Bambang. (2008). Analisis Regresi Terapan dengan SPSS. Yogyakarta: Graha ilmu.

Sukardi. (2012). Metode Penelitian Pendidikan. Jakarta: Bumi Aksara.

Tohirin. (2006). Psikologi Pembelajaran Pendidikan
Agama Islam (Berbasis Integrasi Dan Kompetensi). Jakarta: PT Raja Grafindo Persada.

Tuckman, B. W. (2002). The development and current validity of the Procrastination scale. Educational and Psychological measurement, 51, 473-480.

Warren, Reeve, Fess. (2006). Financial Accounting. $\quad$ South-Western: Thomson.

Woolfolk, Anita. (2004). Educational Psycology $9^{\text {th }}$ Edition. USA: Pearson Education Inc.

Wulandari, Mufit. (2012). Hubungan Motivasi Berprestasi, Selfefficiacy dan Locus of Conrol dengan Prestasi Belajar Ekonomi Siswa Kelas X SMA Negeri 1 Kasihan Tahun Ajaran 2011/2012. Skripsi: Pendidikan Ekonomi UNY 